\title{
Role of Surface
}

Modification on Bacterial

Adhesion of Bio-Implant

Materials 


\section{Role of Surface \\ Modification on Bacterial Adhesion of Bio-Implant Materials}

\section{Machining, Characterization, and Applications}

Santhosh Kumar S

Somashekhar S. Hiremath

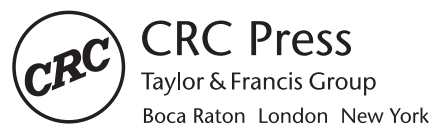

CRC Press is an imprint of the

Taylor \& Francis Group, an informa business 
First edition published 2021

by CRC Press

6000 Broken Sound Parkway NW, Suite 300, Boca Raton, FL 33487-2742

and by CRC Press

2 Park Square, Milton Park, Abingdon, Oxon, OX14 4RN

(C) 2021 Taylor \& Francis Group, LLC

CRC Press is an imprint of Taylor \& Francis Group, LLC

International Standard Book Number-13: 978-0-367-89458-0 (Hardback)

International Standard Book Number-13: 978-1-003-02140-7 (eBook)

Reasonable efforts have been made to publish reliable data and information, but the author and publisher cannot assume responsibility for the validity of all materials or the consequences of their use. The authors and publishers have attempted to trace the copyright holders of all material reproduced in this publication and apologize to copyright holders if permission to publish in this form has not been obtained. If any copyright material has not been acknowledged, please write and let us know so we may rectify in any future reprint.

Except as permitted under U.S. Copyright Law, no part of this book may be reprinted, reproduced, transmitted, or utilized in any form by any electronic, mechanical, or other means, now known or hereafter invented, including photocopying, microfilming, and recording, or in any information storage or retrieval system, without written permission from the publishers.

For permission to photocopy or use material electronically from this work, access www.copyright.com or contact the Copyright Clearance Center, Inc. (CCC), 222 Rosewood Drive, Danvers, MA 01923, 978750-8400. For works that are not available on CCC, please contact mpkbookspermissions@tandf.co.uk

Trademark notice: Product or corporate names may be trademarks or registered trademarks, and are used only for identification and explanation without intent to infringe.

\section{Library of Congress Cataloging-in-Publication Data}

Names: Hiremath, Somashekhar S., author. | Kumar, S. (Santosh), 1953- author.

Title: The role of surface modification on bacterial adhesion of bio-implant materials : machining, characterization, and applications / Somashekhar S. Hiremath and Santhosh Kumar.

Description: First edition. | Boca Raton : CRC Press, 2020. | Includes bibliographical references and index.

Identifiers: LCCN 2020017205 | ISBN 9780367894580 (hardback) | ISBN 9781003021407

(ebook)

Subjects: LCSH: Biomedical materials. | Biomedical materials-Biocompatibility. |

Biomedical materials-Surfaces. Implants, Artificial-Materials.

Classification: LCC R857.M3 H57 2020 | DDC 610.285-dc23

LC record available at https://lccn.loc.gov/2020017205 


\section{Contents}

Preface, ix

Structure of the Book, xiii

Abbreviations, $\mathrm{xv}$

Notations, xvii

\begin{tabular}{ccc} 
CHAPTER 1 - Introduction to Bio-Implants & 1 \\
\hline 1.1 INTRODUCTION & 1
\end{tabular}

1.2 CLASSIFICATIONS OF BIO-IMPLANTS 2

1.3 MATERIALS USED IN IMPLANTS 2

1.4 IMPLANT FAILURE - INFECTIONS 5

1.5 BACTERIAL ADHESION AND BIOFILM FORMATION 5

1.6 EFFECT OF SURFACE ROUGHNESS ON IMPLANTS INFECTION AND WETTABILITY

$\begin{array}{lll}1.7 & \text { SUMMARY } & 10\end{array}$

\begin{tabular}{cc} 
ChAPTER 2 - Surface Modification Techniques & 11 \\
\hline 2.1 INTRODUCTION & 11
\end{tabular}

2.2 OBJECTIVES OF SURFACE MODIFICATION 11

2.3 SURFACE MODIFICATION TECHNIQUES 13 
2.4 TYPES OF SURFACE MODIFICATION TECHNIQUES 14

2.5 SUMMARY 20

ChaPter 3 - Abrasive Flow Finishing: Introduction and Literature Survey

3.1 INTRODUCTION

3.1.1 Super Finishing Processes 22

3.1.1.1 Bonded Abrasives 24

3.1.1.2 Unbonded Abrasives 24

3.1.2 Surface Characteristics 25

3.1.2.1 Surface Topography Terminologies 27

3.1.2.2 Classifications of Surface Roughness Parameters 28

3.1.3 Abrasive Flow Machining/Finishing 30

3.1.3.1 Material Removal Mechanism 30

3.1.3.2 AFM Types Based on the Direction of Media Flow 32

3.1.3.3 Process Parameters 34

3.2 LITERATURE SURVEY 35

3.2.1 Experimental Setups and Experimentation 36

3.2.2 Abrasive Media Development and Characterization 40

3.2.3 Modelling and Optimization 42

3.2.4 Applications 45

3.3 MOTIVATION 47

3.4 OBJECTIVE AND SCOPE OF PRESENT WORK 48

3.4.1 The Detailed Scope of Work-Activities Includes 48

3.5 METHODOLOGY OF RESEARCH WORK 48

$\begin{array}{lll}3.6 & \text { SUMMARY } & 49\end{array}$

ChAPTER 4 - A Novel Approach for Finishing Various Implants: UAFF Process 51

4.1 INTRODUCTION 51 
4.2 DEVELOPMENT OF EXPERIMENTAL SETUP

4.2.1 Stage 1: Unidirectional Abrasive Flow Finishing Process

4.2.2 Stage 2: Closed Loop Unidirectional Abrasive Flow Finishing Process

4.2.2.1 Design Parameters 58

4.3 SUBSYSTEMS 60

4.3.1 Hydraulic Power Pack 60

4.3.2 Hydraulic Cylinder 63

4.3.3 Abrasive Media Cylinder 63

4.3.4 Directional Control Valve with the Manifold Block 63

4.3.5 Pressure Gauges 63

4.3.6 Other Accessories 66

4.4 WORKPIECE AND FIXTURE DESIGN 66

4.4.1 Fixture to Hold the Workpieces for Machinability Study 66

4.4.2 Fixture to Hold Biomaterials Used for Wettability Study 67

4.4.3 Fixture to Hold the Biomaterials Used for Bacterial Adhesion Study 68

4.5 MATERIALS AND ABRASIVE MEDIA DEVELOPMENT 68

4.5.1 Viscoelastic Polymer 69

$\begin{array}{ll}\text { 4.5.2 Plasticizer } & 70\end{array}$

4.5.3 Abrasive Particles $\quad 71$

4.5.4 Preparation of Abrasive Media $\quad 72$

4.6 CHARACTERIZATION OF THE DEVELOPED ABRASIVE MEDIA $\quad 74$

4.6.1 Morphology 74

4.6.2 Thermo Gravimetric Analysis (TGA) 75

4.6.3 Differential Scanning Calorimetry (DSC) $\quad 75$

4.6.4 Tensile Test $\quad 78$

4.6.5 Rheological Properties $\quad 79$

4.6.5.1 Viscosity vs. Shear Rate $\quad 81$

4.6.5.2 Shear Stress vs. Shear Rate 83 
4.6.5.3 Storage Modulus and Loss Modulus vs. Frequency 85

4.6.5.4 Complex Viscosity vs. Frequency 88

$\begin{array}{lll}\text { 4.7 SUMMARY } & 92\end{array}$

ChAPTER 5 - Effect of UAFF Process Parameters on Wettability and Bacterial Adhesion $\quad 93$

5.1 INTRODUCTION 93

5.2 MACHINABILITY STUDY 93

5.3 EFFECT OF SURFACE ROUGHNESS ON WETTABILITY STUDY 95

5.3.1 Characterization of Surface Roughness and Wettability 97

5.3.2 Surface Roughness and Surface Morphology of Finished Surfaces 98

5.3.3 Wettability Study - Contact Angle and Surface Free Energy 101

5.3.4 RSM Modelling 114

5.4 EFFECT OF SURFACE ROUGHNESS ON BACTERIAL ADHESION STUDY 118

5.4.1 Procedure for Bacterial Adhesion Study 119

5.4.2 Finishing of Biomaterials for Bacterial Adhesion Study

5.4.3 Bacterial Adhesion

5.5 SUMMARY

Chapter 6 - Summary and Conclusions

REFERENCES, 139

INDEX, 147 


\section{Preface}

Orthopaedic joint implants such as hip, knee, shoulder, ankle, and elbow prosthesis are used for hard tissue replacement. These are load-bearing joints subjected to high levels of mechanical stress, fatigue, and wear in the normal daily activities of humans. The artificial implants used for these applications should possess structural integrity as well as surface compatibility with the surrounding biological environment for prolonged survivability without complications. Despite the adoption of advanced technology in manufacturing new implants and in surgical and medical management procedures, there are still a large number of implants that are subject to infection. The major causes for implants failure are a fracture, prosthetic dislocation, loosening, excessive wear rate at mating surfaces and its associated debris (although this cause has been much reduced by the use of cross-linked polyethylene), and pre-surgical contamination/infection (i.e. bacterial adhesion). In this book, a focus has been made on the implant failure due to bacterial infections, which is critically important from a clinical perspective when surfaces are made with a finishing process. Bacterial infections on implants are usually initiated through adhesion of bacteria to the implant surface by means of physiochemical interaction between the implant surface and bacteria, that is van der waals forces, electrostatic forces, and gravitational forces. The reversible bacterial adhesion is followed by colonization and formation of biofilm that forms a layer of bacteria binding irreversibly to the implant surface, which is later difficult to remove from implants. The bacterial adhesion on the implant surface depends on the (1) properties of the implant material such as surface topography, surface roughness, surface chemistry, and surface energy; (2) properties of the bacteria such as surface charge, surface hydrophobicity hydrophilicity, and appendages; and (3) properties of the surrounding environment such as type of antibiotics and associated flow condition, temperature, $\mathrm{pH}$ value, a period of exposure, chemical treatment, and 
bacterial concentration. In particular, surface roughness and topography are the most influencing parameters because studies show that surface roughness increase the surface area of the material and also the depression, grooves, pits, scratches, and crevices in the rough surfaces influences the bacterial adhesion and acts as favourable sites for colonization and biofilm formation.

The near-net-shape of the bio-implants with the required surface finish is achieved by various finishing steps after the primary machining process. After the pre-fabrication, implants are subjected to the grinding process at the end. Final finishing of these surfaces is performed using polishing integrated with multi-axis $\mathrm{CNC}$ machines, vibratory abrasive polishing, free abrasive polishing, fixed abrasive polishing, belt polishing, and so on, which have all been comprehensively used in the past few decades to remove the finer irregularities and these techniques along with some of the advanced surface modification techniques are explained in this book.

Most of the implants have a complex and partly freeform surface that raises the difficulty in finishing at one step, and also one should have the knowledge of frequently changing contact conditions while performing finishing operation. There is a need for a technique that can be used to finish the complex surfaces of orthopaedic implants without changing its contact condition and without disturbing the dimensional accuracy. Abrasive flow finishing is one such process, in which flexible abrasive media is used to finish the complex surfaces. Previous studies have demonstrated that this process is capable of finishing complex internal and external surfaces and also freeform surfaces with controlled surface topography without disturbing the dimensional accuracy. Although there have been studies on the finishing of freeform surfaces using this process, understanding the biocompatibility of surfaces finished with this process is still far from the complete study.

In the present research work, to overcome the challenges associated with conventional finishing processes to finish complex internal and external surfaces along with free form surfaces, a unidirectional abrasive flow finishing (UAFF) process is developed in which abrasive media flows only in one direction to achieve the uniform lay patterns on the work surface in one direction with the required finish, which finds wide application in lubrication, biomedical, and surface engineering. The experimental setup mainly consists of the hydraulic power pack, a 
hydraulic cylinder, an abrasive media cylinder, direction control valves, and pressure gauges.

In the present work, a viscoelastic polymer-based abrasive media is developed using a two-roll mill process. The selected constituents are viscoelastic polymer: silicone rubber (38\%), plasticizer: silicone oil (12\%) reinforced with suitable abrasive particles: $\mathrm{SiC}$ (50\%). The developed abrasive media is subjected to different characterization studies such as the morphology using a high-resolution scanning electron microscope (HRSEM) - Inspect F50, thermal properties using thermo gravimetric analysis (TGA) - SDT Q600 instrument, and differential scanning calorimetry (DSC) - Model Q2000 V24 instrument. The tensile property of the abrasive media is measured using the Universal testing machine -ZwickRoell. Further, rheological properties such as viscosity, shear stress, storage modulus, loss modulus, loss tangent, and complex viscosity are ascertained using the Anton Paar Physica MCR 301 rheometer instrument. The rheological properties are studied at different temperatures: $25^{\circ} \mathrm{C}, 35^{\circ} \mathrm{C}, 45^{\circ} \mathrm{C}$, and $55^{\circ} \mathrm{C}$ to study the behaviour of abrasive media under different temperature condition.

The experimentation has been carried out at various levels to investigate the performance of the developed unidirectional abrasive flow finishing setup. Machinability study has been carried out on different engineering materials having different hardness values such as aluminium, brass, copper, and mild steel machined with varying number of cycles. The objective of this experiment is to finish the biomaterials for different cycles and to study the effect of the UAFF process on the surface roughness, surface morphology, bearing area curve (BAC), and wettability of the biomaterial surfaces. The selected process parameters are number of cycles: 3, 6, 9, and pressure: 40 bar, 50 bar, and 60 bar. The obtained surface roughness and BAC are measured using optical profilometer - Wyko NT1100 instrument, and morphology of the surface is studied using an HRSEM image. Further, the wettability of the finished surface is studied by measuring the contact angle $(\theta)$ for three different liquids - water, formamide, and diiodomethane by sessile drop technique using contact angle Goniometer - GBX-Digidrop MCAT instrument. The measured contact angles are used to ascertain the surface free energy using the van-Oss-Chaudhury-Good equation. Further, response surface methodology (RSM) is used to optimize the input parameters such as a number of cycles and pressure to obtain the desired output responses, namely, average surface roughness $\left(R_{\mathrm{a}}\right)$, and material removed (MR). 
Bacterial adhesion study has been carried out on machined biomaterials to investigate the influence of process parameters on surface roughness and bacterial adhesion. The developed setup has been used to finish the biomaterials - stainless steel (SS316L) and titanium alloy (Ti-6Al-4V) with two different abrasive media (220 mesh and 400 mesh) and a varying number of cycles (3 and 6). The purpose of this study is to evaluate the effect of this finishing process on enhancing surface characteristics such as surface roughness, surface morphology, and its role in initial bacterial adhesion. Optical profilometer and an HRSEM are used to examine the surface roughness and surface morphology of the finished surfaces. Further, for the bacterial adhesion study, both Escherichia coli (E. coli) and Staphylococcus aureus (S. aureus) are selected because these bacterial strains are commonly found on orthopaedic implant-related infections.

The procedure followed during the experiments and experimental findings is detailed in the book under various chapters with different headings along with an introduction chapter, which covers the different surface modification techniques. 


\section{Structure of the Book}

Chapter 1 covers introduction to bio-implants, classifications of various implants, different materials used to manufacture implants, the reason for implant failures, failure due to bacterial adhesion and biofilm formation, and a broad literature survey.

A wide variety of established methods developed for implant surface modification such as mechanical, chemical, and thermal processes are summarized in Chapter 2. Further, this chapter mainly focuses on implant surface roughness and topographical features that influence implant failures. After obtaining a panoramic view on the topic through the literature survey, the objective and scope of the book are carried out, followed by the motivation.

Chapter 3 introduces the readers to different types of finishing processes, the importance of finishing processes, surface topography, and surface morphology. Different variants of abrasive flow machining, material removal mechanism, and process parameters are discussed in detail. A literature survey on various aspects of the abrasive flow machining, motivation, objectives, and methodology of the research work is presented in this chapter.

Chapter 4 contains the development and fabrication details of the experimental setup carried out at different stages. It also includes the information on materials and various fixtures developed in the present work to carry out the experimentation. This chapter also consists of a selection of materials and preparation steps followed in the development of abrasive media. This section also highlights the different characterization studies used to study the properties of the abrasive media and results.

Chapter 5 presents the results and analysis of the experimentation carried out in the present research work. Machinability study on different work materials has been carried out. Further, surface roughness and 
morphology of the abrasive flow finished work surfaces on wettability, and bacterial adhesion is presented at the end of the chapter.

Chapter 6 includes conclusions drawn based on the experimental studies carried out in the present research work, and the scope for future work is highlighted. The contribution of the work is also listed in this chapter. 


\section{Abbreviations}
AA
Aluminium alloy
AFF
Abrasive flow finishing
AFM
Abrasive flow machining
AISI
American Iron and Steel Institute
Al
Aluminium
$\mathrm{Al}_{2} \mathrm{O}_{3}$
Aluminium oxide
ANN
Artificial Neural Network
ANOVA Analysis of variance
AOA NJRR Australian Orthopedic Association National Joint Replace- ment Registry
ASTM American Society for Testing and Materials
ATCC American Type Culture Collection
$\mathrm{B}_{4} \mathrm{C} \quad$ Boron carbide
BAC Bearing area curve
CCD Central composite design
C-D Convergent-Divergent
CFAAFM Centrifugal force assisted abrasive flow machining
CFD Computational fluid dynamics
CLUAFF Closed loop unidirectional abrasive flow finishing
CNC Computer numerical control
Cu Copper
DBG-AFF Drill bit guided-abrasive flow finishing
DCV Directional control valve
DDS Data dependent systems
DI Deionized water
DSC Differential scanning calorimetry
E. coli Escherichia coli
ECAFM Electro-chemical aided abrasive flow machining
EDAX Energy dispersive X-ray analysis 


$\begin{array}{ll}\text { EDM } & \text { Electrical discharge machining } \\ \text { GA } & \text { Genetic algorithms } \\ \text { GMDH } & \text { Group method of data handling } \\ \text { GP } & \text { Gel point } \\ \text { GRA } & \text { Grey relational analysis } \\ \text { HB } & \text { Hardness Brinell } \\ \text { HRSEM } & \text { High resolution scanning electron microscope } \\ \text { ID } & \text { Internal diameter } \\ \text { LB } & \text { Lysogeny broth } \\ \text { MAFM } & \text { Magneto abrasive flow machining } \\ \text { MEMS } & \text { Micro-electro-mechanical-systems } \\ \text { MR } & \text { Material removed } \\ \text { MRAFF } & \text { Magneto rheological abrasive flow finishing } \\ \text { MRR } & \text { Material removal rate } \\ \text { MS } & \text { Mild steel } \\ \text { MWD } & \text { Molecular weight distribution } \\ \text { OD } & \text { Outer diameter } \\ \text { PII } & \text { Prosthetic implant infection } \\ \text { R-AFF } & \text { Rotational-abrasive flow finishing } \\ \text { R-MRAFF } & \text { Rotational magneto rheological abrasive flow finishing } \\ \text { RMS } & \text { Root mean square } \\ \text { RSM } & \text { Response surface methodology } \\ \text { S. aureus } & \text { Staphylococcus aureus } \\ \text { S/N } & \text { Signal-to-noise ratio } \\ \text { SEM } & \text { Scanning electron microscope } \\ \text { SiC } & \text { Silicon carbide } \\ \text { SR } & \text { Silicone rubber } \\ \text { SS } & \text { Stainless steel } \\ \text { TGA } & \text { Thermo gravimetric analysis } \\ \text { Ti } & \text { Titanium } \\ \text { UAAFM } & \text { Ultrasonic assisted abrasive flow machining } \\ \text { UAFF } & \text { Unidirectional abrasive flow finishing } \\ \text { USA } & \text { United States of America } \\ \text { UV } & \text { Ultraviolate } \\ \text { V } & \text { Vanadium } \\ & \end{array}$




\section{Notations}

$\dot{\gamma} \quad$ Shear rate, $1 / \mathrm{s}$

$\gamma^{-} \quad$ Base component, $\mathrm{mN} / \mathrm{m}$

$\boldsymbol{\theta}^{\perp} \quad$ Contact angle - Perpendicular direction, deg

$\boldsymbol{\theta}^{\|} \quad$ Contact angle - Parallel direction, deg

$\gamma^{+} \quad$ Acid component, $\mathrm{mN} / \mathrm{m}$

$\gamma^{L W}$

$\gamma^{T O T}$

Lifshitz-van der Waals or dispersive component, $\mathrm{mN} / \mathrm{m}$

Total surface tension of the liquid, $\mathrm{mN} / \mathrm{m}$

$\omega \quad$ Angular velocity, $\mathrm{rad} / \mathrm{s}$

$\boldsymbol{\delta} \quad$ Oscillation phase angle, deg

$\tau \quad$ Shear stress, $\mathrm{Pa}$

$\boldsymbol{\eta} \quad$ Viscosity, Pa.s

$\Delta \boldsymbol{\theta} \quad$ Change in contact angle, deg

$\boldsymbol{\eta}^{\prime} \quad$ Dynamic viscosity (In-phase), Pa.s

$\eta^{\prime \prime} \quad$ Dynamic viscosity (Out-of-phase), Pa.s

$\eta^{*} \quad$ Complex viscosity, Pa.s

$\phi_{0} \quad$ Angular amplitude of oscillation

$\rho_{a}, \rho_{p}, \rho_{o} \quad$ Density of abrasive particles, density of polymer and density of oil, $\mathrm{kg} / \mathrm{m}^{3}$

$\boldsymbol{\theta}_{\boldsymbol{D}} \quad$ Contact angle - Diiodmethane, deg

$\boldsymbol{\theta}_{\boldsymbol{F}} \quad$ Contact angle - Formamide, deg

$\rho_{m} \quad$ Density of abrasive media, $\mathrm{kg} / \mathrm{m}^{3}$

$\Delta \boldsymbol{R}_{\boldsymbol{a}} \quad$ Change in average surface roughness, $\mu \mathrm{m}$

$\boldsymbol{\eta}_{\boldsymbol{t}} \quad$ Total efficiency

$\boldsymbol{\theta}_{\boldsymbol{W}} \quad$ Contact angle - Water, deg

$A 1$ Area of peak, $\mu \mathrm{m}^{2}$

A2 Area of valley, $\mu \mathrm{m}^{2}$

$\boldsymbol{A}_{\boldsymbol{a}} \quad$ Area of abrasive cylinder, $\mathrm{m}^{2}$

$\boldsymbol{A}_{\boldsymbol{f}} \quad$ Area of hydraulic cylinder piston end (forward direction), $m$ 


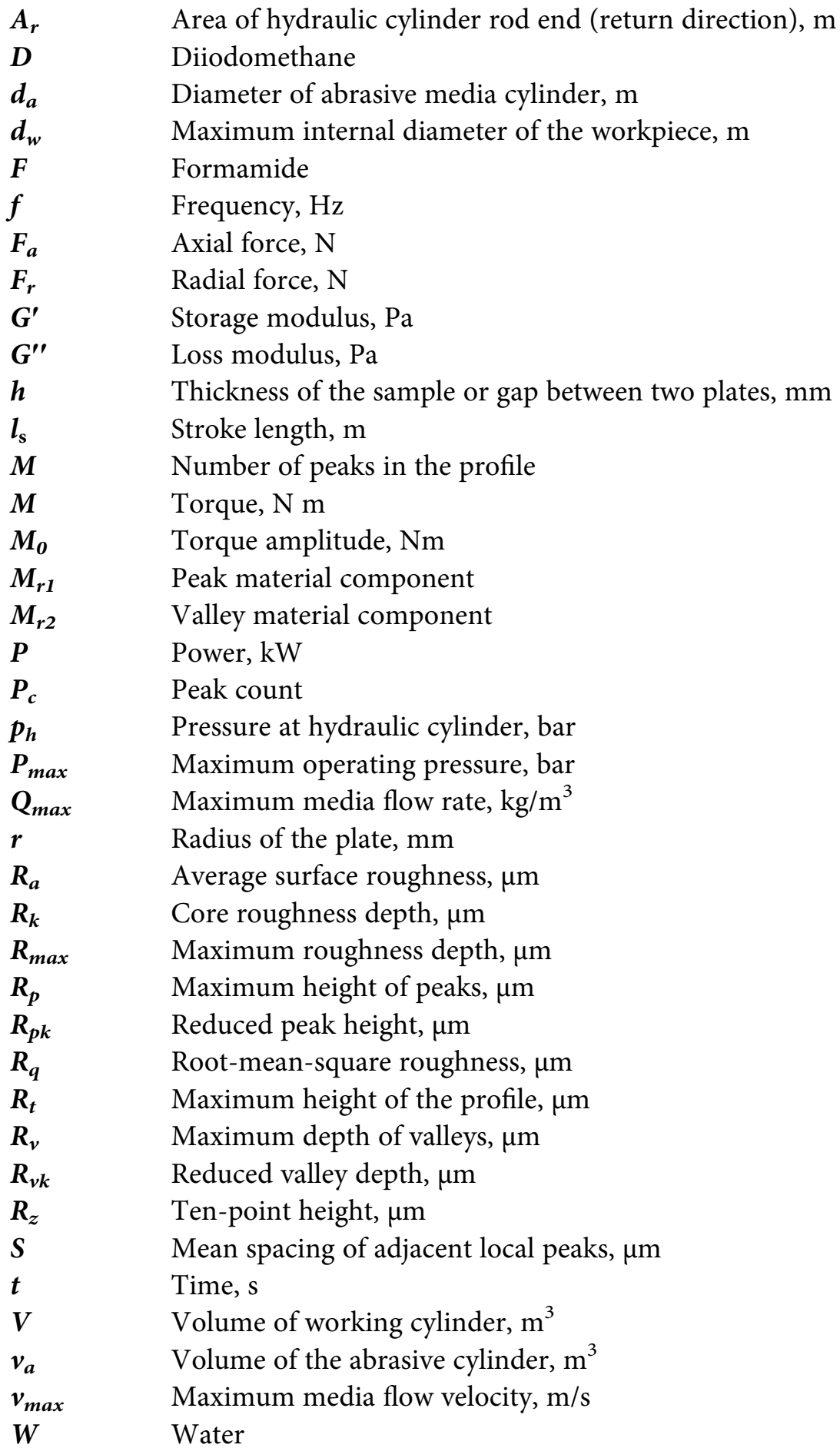


$\boldsymbol{w}_{\boldsymbol{a}}, \boldsymbol{w}_{\boldsymbol{p}}, \boldsymbol{w}_{\boldsymbol{o}} \quad$ Weight percentage of abrasive particles, wt $\%$ of polymer and $\mathrm{wt} \%$ of oil

$W_{c} \quad$ Weight of the constituent, $\mathrm{kg}$

$\boldsymbol{w}_{\boldsymbol{c}} \quad$ Weight percentage of each constituent

$\boldsymbol{w}_{\boldsymbol{m}} \quad$ Total weight of abrasive media, $\mathrm{kg}$

$\Delta_{q} \quad$ RMS slope of the profile

$\lambda_{q} \quad$ RMS wave length, $\mu \mathrm{m}$ 


\section{Introduction to Bio-Implants}

\subsection{INTRODUCTION}

Bio-implants are artificial medical devices used to replace the missing biological system and the damaged biological system, and also to support or enhance the existing biological structure. These implants can be of many types, such as load-bearing implants used in orthopaedic applications, dental implants used in restoring the functionality and appearance of natural teeth, implants used in cardiovascular system, and many more. Metallic biomaterials are widely used among other materials, especially in load-bearing implants and internal fixation devices, due to their superior characteristics such as high tensile strength, high yield strength, resistance to fatigue loading, resistance to creep, high corrosion resistance, and biocompatibility. Most popular metallic biomaterials in use today are stainless steel, cobalt-chromium alloys, titanium, and titanium alloys. These materials are used in cardiovascular, orthopaedic, dentistry, craniofacial, and otorhinology implants. The implants are usually manufactured using milling, casting, forging, compression moulding, powder metallurgy, and rapid prototype techniques; further features are generated using drilling, electrical discharge machining (EDM), electron beam machining (EBM), laser beam machining (LBM), and ultrasonic machining (USM).

According to statistics in the United States, around 1.32 million implantrelated infections are registered every year and amount to devastating 
consequences that expose patients to high morbidity and mortality. The implant infections are mainly associated with bacterial adhesion and biofilm formation. Bacterial adhesion and biofilm formation, in turn, are influenced by several micro-environmental factors. Some of such micro-environmental factors listed in the literature are mass transport, surface charge, surface conditioning, hydrophobicity, surface topography, and surface roughness. This chapter emphasises on the different types of implants, materials classifications, and bacteria-related infections under various sections.

\subsection{CLASSIFICATIONS OF BIO-IMPLANTS}

Bio-implants are prostheses devices used to regularize physiological functions. They are made up of biosynthetic materials like collagen, and tissueengineered products like artificial skin or tissues. Most bio-engineered products like cardiac pacemakers and orthopaedic artificial implants are also covered under bio-implants because they are implanted entirely in the patient's body. Bio-implants are mostly classified at a broader level such as orthopaedic, cardiovascular, dental, ophthalmic, and neurostimulation implants; these are listed in Table 1.1.

\subsection{MATERIALS USED IN IMPLANTS}

The materials used in the implants should be a biocompatible, corrosion resistance, and wear resistance; they should have excellent mechanical properties and better Osseo-integration; and should not create any effect on biological system/tissue (Mahajan and Sindhu, 2018). All the available materials on earth cannot be used as biomaterials. Researchers have developed plenty of materials that can be used as biomaterials and are continually working towards developing new biocompatible materials. Some of the factors affecting implant biomaterial are chemical factors: these include three basic types of corrosion: general, pitting, and crevice; surface specific factors: the events at the bone-implant interface can be divided into the behaviour of the implant material, the host response; electrical factors: physiochemical methods, morphologic methods, and biochemical methods; mechanical factor: modulus of elasticity, tensile or compressive forces, and elongation and metallurgical aspects. The biomaterials are classified under metals, ceramics, and polymers. Some of the major materials used in the implants are listed as follows: 
TABLE 1.1 Broad classifications of bio-implants (Global Trends \& Forecasts till 2017)

\begin{tabular}{|c|c|}
\hline Implant system & Different types under each implants system \\
\hline \multirow[t]{11}{*}{ Cardiovascular Implants } & - Pacing devices \\
\hline & - Implantable cardiac pacemakers \\
\hline & - Stents and related implants \\
\hline & 1. Coronary stents \\
\hline & 2. Peripheral stents \\
\hline & 3. Stent-related implants \\
\hline & - Structural cardiac implants \\
\hline & - Heart valves \\
\hline & - Tissue heart valves \\
\hline & - Mechanical heart valves \\
\hline & - Implantable heart monitors \\
\hline \multirow[t]{5}{*}{ Spinal Implants } & - Thoracolumbar implants \\
\hline & - Intervertebral spacers \\
\hline & - Machined allograft spacers \\
\hline & - Cervical implants \\
\hline & - Implantable spinal stimulators \\
\hline \multirow[t]{4}{*}{ Orthopaedics and Trauma } & - Reconstructive joint replacements \\
\hline & - Knee replacement implants \\
\hline & - Hip replacement implants \\
\hline & - Extremities \\
\hline
\end{tabular}

1. Shoulder implants

2. Elbow replacements

3. Ankle implants

4. Other joint replacements fusion products 
TABLE 1.1 (Cont.)

\begin{tabular}{|c|c|}
\hline Implant system & $\begin{array}{l}\text { Different types under each implants system } \\
\text { - Orthobiologics } \\
\text { - Trauma implants } \\
\text { - Sports medicine }\end{array}$ \\
\hline Dental Implants & $\begin{array}{l}\text { - Dental screw } \\
\text { - Abutment } \\
\text { - Crown and bone graft }\end{array}$ \\
\hline Ophthalmic Implants & $\begin{array}{l}\text { - Intraocular lens } \\
\text { - Glaucoma and other lenses }\end{array}$ \\
\hline Neurostimulators Implants & $\begin{array}{l}\text { - Cortical stimulators } \\
\text { - Deep brain stimulators } \\
\text { - Sacral nerve stimulators } \\
\text { - Spinal cord stimulators } \\
\text { - Vagus nerve stimulators }\end{array}$ \\
\hline
\end{tabular}

Metals: Titanium and its alloys are the metals of choice for dental and orthopaedic implants. Some of the commonly used metals are stainless steel, titanium and titanium alloys, gold, cobalt-chromium alloys, zirconium, niobium, tantalum, and so on.

Ceramics: Ceramics are non-organic, non-metallic, and non-polymeric materials manufactured by compacting and sintering at elevated temperatures. The entire implant may be made of ceramic, or this may be applied as a coat to a metallic core. Some of the ceramics biomaterials are aluminium oxide, zirconium oxide, hydroxyapatite, tricalcium phosphate, tetracalcium phosphate, calcium pyrophosphate, fluorapatite, brushite, carbon glass, pyrocarbon, and bioglass.

Polymers: Polymers are most commonly used for liners and small implants. These materials can be used alone or mixed with some other ceramics. Commonly used polymers are polyethylene, polyamide, ultra-high molecular weight polyethylene (UHMW-PE), polymethyl methacrylate, 
polypropylene (PP), polytetrafluoro-ethylene, silicone rubber (SR), and polyurethane (Sykaras et al., 2000).

\subsection{IMPLANT FAILURE - INFECTIONS}

Orthopaedic joint implants such as hip, knee, shoulder, ankle, and elbow prosthesis are used for hard tissue replacement. These are loadbearing joints subjected to a high level of mechanical stress, fatigue, and wear in the normal daily activity of humans. The artificial implants used for these applications should possess structural integrity as well as surface compatibility with the surrounding biological environment for prolonged survivability without complications and damage (Choudhury et al., 2017; Lysaght and O'Loughlin, 2000; Navarro et al., 2008; Ribeiro et al., 2012). Most of the dental implants also fail due to poor primary stability, bacterial infection, manufacturing defect, and improper selection of surgical protocol. Despite the adoption of advanced technology in manufacturing these new implants and in surgical and medical management procedures, the number of revisions of total knee and hip arthroplasties keeps on increasing over the period (Moriarty et al., 2016).

A significant cause for the implant failure is a fracture, prosthetic dislocation, loosening, excessive wear rate at mating surfaces and its associated debris, and pre-surgical contamination/infection (i.e., bacterial adhesion). American Joint Replacement Registry annual report (2018) collected between 2012and2017 showed that $8.2 \%$ of 47,378 hip arthroplasties and $7.9 \%$ of 40,488 knee arthroplasties are due to the infection and inflammatory reactions. The National Joint Registry for England, Wales, Northern Ireland, and the Isle of Man surgical data of 2018 report shows that the overall $0.72 \%$ of hip replacement, $0.93 \%$ of knee replacement, and $6 \%$ of shoulder replacement results in implants-related infections. Similarly, it was reported in the Australian Orthopaedic Association National Joint Replacement Registry (AOA NJRR) annual report (2018) that, overall, less than $1 \%$ of revision of knee and hip arthroplasties accounts due to infection.

\subsection{BACTERIAL ADHESION AND BIOFILM FORMATION}

Bacterial infections on implants are usually initiated through the adhesion of bacteria to the implant surface by means of physiochemical interaction between the implant surface and bacteria, that is van der Waals forces, electrostatic forces, and gravitational forces (Arciola 
et al., 2015; Koseki et al., 2014). The reversible bacterial adhesion is followed by colonization and formation of biofilm that forms a layer of bacteria binding irreversibly to the implant surface that is later difficult to remove from the implants (Chan et al., 2017; Koseki et al., 2014). These adhered bacteria further forma colony of the bacteria that later on forms a thick layer of the dense mass of the bacteria called biofilms.

The bacterial adhesion on the implant surface depends on the

1. Properties of the implant material such as surface topography, surface roughness, surface chemistry, and surface energy;

2. Properties of the bacteria such as surface charge, surface hydrophobicity (contact angle, $\theta>90^{\circ}$ )/hydrophilicity (contact angle, $\left.\theta<90^{\circ}\right)$; and appendages; and

3. Properties of the surrounding environment, such as the type of antibiotics and its associated flow condition, temperature, $\mathrm{pH}$ value, a period of exposure, chemical treatment, and bacterial concentration. Figure 1.1 shows the schematic diagram of bacterial adhesion and the effects of implant material properties.

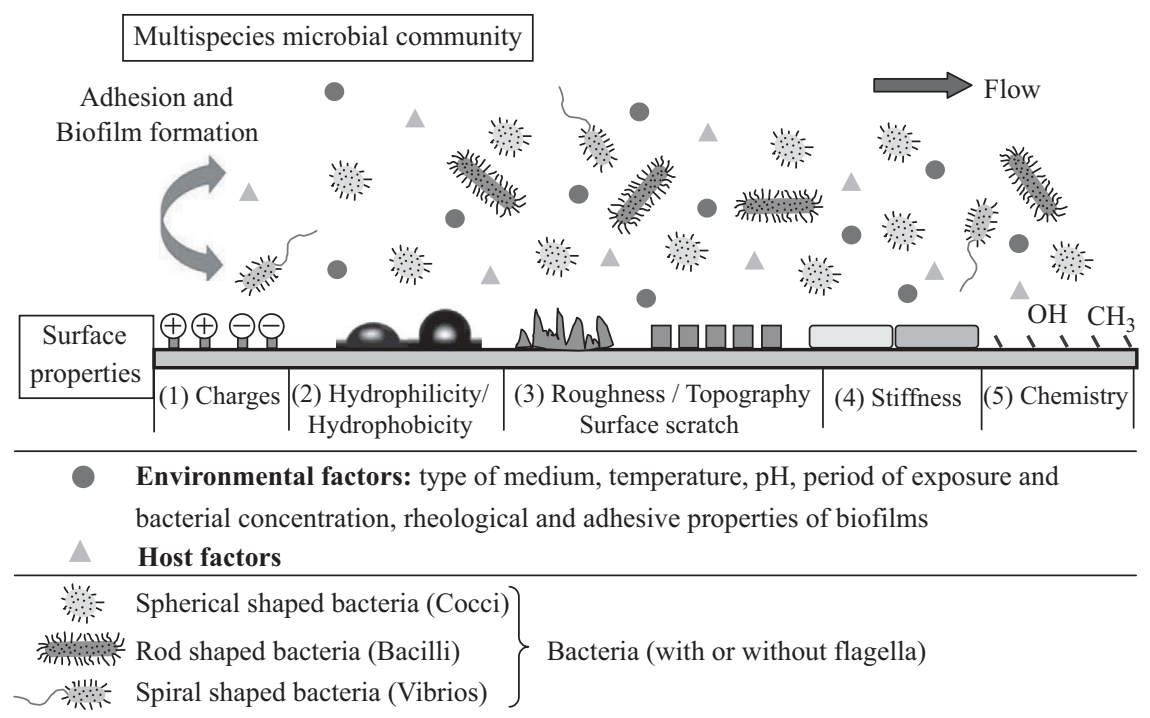

FIGURE 1.1 Schematic diagram of bacterial adhesion and the effect of implant material properties (Song et al., 2015). 


\subsection{EFFECT OF SURFACE ROUGHNESS ON IMPLANTS INFECTION AND WETTABILITY}

In particular, surface roughness and topography are the most influencing parameters because studies show that surface roughness increases the surface area of the material, in turn, increases bacterial adhesion. Here, the focus has been made on the relation between the surface roughness and the bacterial adhesion, which is critically important from a clinical perspective when the work surfaces are finished with the finishing process. The depression, grooves, pits, scratches, and crevices in the rough surfaces influences the bacterial adhesion and acts as favourable sites for colonization and biofilm formation (An and Friedman, 2000; Barbour et al., 2007; Cox et al., 2017; Hocevar et al., 2014; Ribeiro et al., 2012; Wassmann et al., 2017; Yoda et al., 2014). These topographical features depend on the type of machining, finishing, coating, and surface treatment procedure followed. The near-net-shape of the bio-implants with the required surface finish is achieved by various finishing steps after the primary machining process. After the pre-fabrication, implants are subjected to the grinding process at the end. Final finishing of these surfaces is performed using either polishing integrated with multi-axis CNC machines or vibratory abrasive polishing, free abrasive polishing, fixed abrasive polishing, belt polishing, and so on. These processes have all been comprehensively used in the past decades (Bohinc et al., 2016; Cox et al., 2017; Kang and Fang, 2018; Turger et al., 2013) to remove the finer irregularities. It was estimated that polishing processes typically accounted for $10 \%$ to $15 \%$ of the total manufacturing cost and detailed review on different manufacturing and finishing processes used in implant manufacturing are detailed in a study conducted (Petare and Jain, 2018).

It is understood that, despite the adoption of advanced technology in manufacturing the implants and in surgical and medical management procedures, there are still a large number of implants that are subject to failure due to the surface finish achieved on the implant surfaces. The major causes for implants failure are a fracture, prosthetic dislocation, loosening, excessive wear rate at mating surfaces and its associated debris, and pre-surgical contamination/infection (i.e., bacterial adhesion). Surfaces roughness is one of the factors that influence the bacterial adhesion on implants and acts as favourable sites for colonization and biofilm formation leading to prosthetic implant infections (PIIs). A further effect of surface roughness on the wettability of surfaces is explained subsequently. 
Wettability of the surface is strongly influenced by surface energy, surface roughness, and liquid surface tension. Among these, the surface roughness of any work surfaces is the most critical parameter considered in many applications and processes, where the wetting and the adhesion play a significant role. Some of the critical applications are lubrication, implants, pharmaceutical manufacturing, oil recovery, pharmacy, adhesive, coating, semiconductor, spray quenching, textiles, paper printing, polymers, dental, optics, medical field, preservation of the building, biology, cosmetics, high performance microfluidic devices, self-cleaning surfaces, and biomedical products (Guo et al., 2014; Gui et al., 2018).

Wettability is the ability of the solid surfaces to be wetted when it is in contact with any liquids by reducing liquid surface tension such that the liquid spreads over the surface and wets it. It can be described quantitatively by measuring the tangential contact angle between a liquid droplet and a solid surface-air interface. If the contact angle $(\theta)$ is less than $90^{\circ}$ $\left(\theta<90^{\circ}=\right.$ hydrophilic surface $)$, it shows that the surface has high wettability characteristics; and if it is greater than $90^{\circ}\left(\theta>90^{\circ}=\right.$ hydrophobic surface), it shows low wettability (Law and Zhao, 2016). Figure 1.2 shows the schematic nature of contact angle for different work surfaces (Nuraje et al., 2013).

There are many well-developed processes to modify surfaces, such as the following:

1. Non-deforming methods - polishing, machining, acid etching, and anodizing.

2. Deforming methods - sandblasting, shot peening, and surface mechanical attrition treatment.

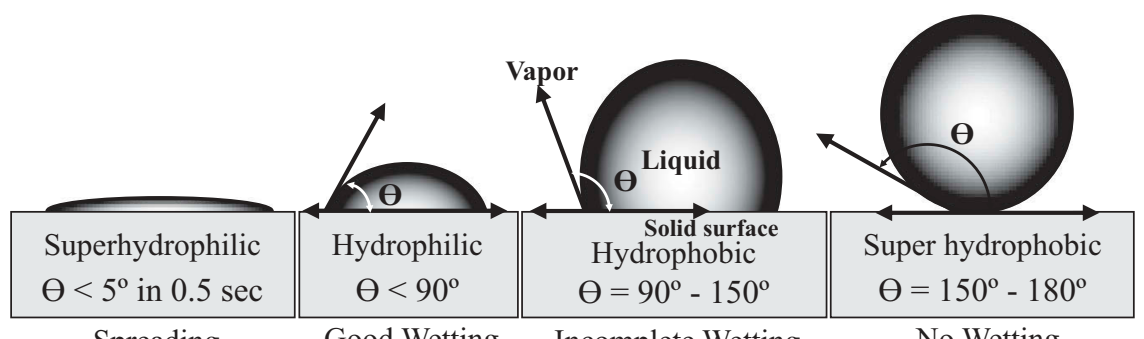

Spreading

Good Wetting Incomplete Wetting

No Wetting

FIGURE 1.2 Nature of contact angle for different work surfaces. 
The above methods are presently in use to control the roughness and wettability of metal surfaces. All these treatments control the roughness and wettability of surfaces but alter the strength of materials due to the formation of residual stresses and fine grains (Arifvianto et al., 2012).

Wenzel (1936) was the first to describe the wetting concept in a solid substrate having rough surfaces using a thermodynamic argument. The tilting plate principle was used to measure the contact angle, and he stated that the wetting properties of a solid substrate are directly proportional to the roughness of the surface wetted. Similarly, Cassie and Baxter (1944) extended the research on the analysis of wetting of porous surfaces. It is reported that when a liquid wets the porous surfaces, air pockets are formed between surface and liquid, and the interface becomes a composite surface. Based on the earlier-mentioned models, many researchers have studied the wetting of rough surfaces experimentally and analytically. Kubiak et al. (2011) established a mechanism of wettability versus surface roughness of different engineering surfaces. In the study conducted by Kubiak et al. (2011), several engineering materials such as aluminium alloy: AA7064; titanium alloy: Ti-6Al-4V; steel: AISI 8630; copper alloy, and ceramic and poly-methylmethacrylate surfaces are polished with a different process, and four different roughness values are obtained. Further, these surfaces are subjected to contact angle measurement, and conclusions are drawn based on the experimentation. It is observed that roughness has a strong influence on the wettability of engineering surfaces, and the same has been found on different materials also. Fischer et al. (2014) carried out the wettability study on the steel surfaces and reported that the directional spreading and the wettability of the surfaces are strongly influenced by anisotropic surface properties, and droplet takes place along the grooves, which leads to droplet elongation in one direction.

Li et al. (2015) experimentally identified the wetting of irregularly micro-structured surfaces. The silicon surfaces are machined with rubbing, grinding, and polishing with a $0.22 \mu \mathrm{m}-3.58 \mu \mathrm{m}$ depth, and wetting properties were investigated. This study concluded that the contact angle increases with an increase in the roughness factor and the aspect ratio on the irregular micro-structured surfaces. Also, anisotropic wetting properties were observed on regularly micro-grooved surfaces but not on the irregularly micro-grooved surface. Liang et al. (2015) conducted the wettability experiments on the aluminium alloy - AA6061 and nylon GF30 polished with ten different grit sandpapers to identify anisotropic 
wetting characteristics versus roughness on machined surfaces. It was concluded that roughness has a significant influence on anisotropic wetting on machined surfaces. As the roughness decreases, anisotropic wetting reduces. In the direction perpendicular to lay energy, a barrier exists, which is the main reason for anisotropic wetting. Gui et al. (2018) carried out the wettability experiments on titanium-coated textured surfaces. This study helps in understanding the anisotropic wettability of the surfaces and its applications in different areas, including orthopaedic titanium implants.

From the above literature, it is concluded that the wetting of the surface finds wide applications in many areas. Surface roughness has a great influence on the wettability of the surfaces; especially roughness range and topographical features (i.e., lay direction, width, depth, etc.) decide the anisotropic wetting behaviour of the surfaces. Further study in this direction on work surfaces finished with a different technique and how these surfaces affect the wetting is essential to understand.

\subsection{SUMMARY}

This chapter gives a glimpse of different types of implants and materials used in the manufacturing of implants, and also implants' failures are explained in detail. Bacterial infections on the implants are explained along with the biofilm formation on the implants. Further, broad literature on the effect of surface roughness on the bacterial infection and wettability of the implants materials surfaces are elaborated in this chapter. 


\section{References}

Aggarwal, S.L. (1987) Rubber Technology, 3rd Edition, M.Morton, Ed., Van Nostrand Reinhold, New York.

Aho, J., J.P.Boetker, S.Baldursdottir, and J.Rantanen (2015) Rheology as a tool for evaluation of melt processability of innovative dosage forms. International Journal of Pharmaceutics, 494(2), 623-642.

Alam, F., V.Verma, and K.Balani (2015) Fundamentals of surface modification. Biosurfaces: A Materials Science and Engineering Perspective, 126-145. doi:https://doi.org/ 10.1002/9781118950623.ch4.

Ali-Tavoli, M., N.Nariman-Zadeh, A.Khakhali, and M.Mehran (2006) Multi-objective optimization of abrasive flow machining processes using polynomial neural networks and genetic algorithms. Machining Science and Technology, 10(4), 491-510.

An, Y.H. and R.J.Friedman (2000) Handbook of Bacterial Adhesion, Humana Press Inc., Totowa, NJ.

Arciola, C.R., C.Campoccia, G.D.Ehrlich, and L.Montanaro (2015) Biofilm-based implant infections in orthopaedics. Biofilm-based healthcare-associated infections: volume I. Advances in Experimental Medicine and Biology, 830, 29-46.

Arifvianto, B., Suyitno, and M.Mahardika (2012) Effects of surface mechanical attrition treatment (SMAT) on a rough surface of AISI 316L stainless steel. Applied Surface Science, 258(10), 4538-4543.

Barbour, M.E., D.J.O'Sullivan, H.F.Jenkinson, and D.C.Jagger (2007) The effects of polishing methods on surface morphology, roughness and bacterial colonisation of titanium abutments. Journal of Materials Science: Materials in Medicine, 18(7), 1439-1447.

Bhushan, B. (2013) Introduction to Tribology, 2nd Edition, John Wiley \& Sons Ltd, The Atrium, West Sussex, United Kingdom.

Bikiaris, D. (2010) Microstructure and properties of polypropylene/carbon nanotube nanocomposites. Materials, 3(4), 2884-2946.

Bio-Implants Market - by Type (Cardiovascular, Spine, Orthopedics, Trauma, Dental), by ROA (Surgical/Injectable), by Origin (Allo/Auto/Xenograft, Synthetic) \&Materials (Ceramics, Biomaterial, Alloys, Polymers) - Global Trends \&, Forecasts till 2017: weblink: www.marketsandmarkets.com/pdfdownloadNew.asp?id=728

Bohinc, K., G.Drazic, A.Abram, M.Jevsnik, B.Jersek, D.Nipic, M.Kurincic, and P.Raspor (2016) Metal surface characteristics dictate bacterial adhesion capacity. International Journal of Adhesion and Adhesives, 68, 39-46. 
Cassie, A.B.D. and S.Baxter (1944) Wettability of porous surfaces. Transactions of the Faraday Society, 40, 546-551.

Chan, C.W., L.Carson, G.C.Smith, A.Morelli, and S.Lee (2017) Enhancing the antibacterial performance of orthopaedic implant materials by fibre laser surface engineering. Applied Surface Science, 404, 67-81.

Chen, W.C., K.L.Wu, and B.H.Yan (2014) A study on the application of newly developed magneto-elastic abrasive to improving the surface roughness of the bore. International Journal of Advanced Manufacturing Technology, 73(9-12), 1557-1566.

Cheng, C.T., G.Zhang, and S.To (2016) Wetting characteristics of bare micro-patterned cyclic olefin copolymer surfaces fabricated by ultra-precision raster milling. RSC Advances, 6, 1562-1570.

Choudhury, D., M.Vrbka, A.B.Mamat, I.Stavness, C.K.Roy, R.Mootanah, and I.Krupka (2017) The impact of surface and geometry on coefficient of friction of artificial hip joints. Journal of the Mechanical Behavior of Biomedical Materials, 72, 192-199.

Cox, S.C., P.Jamshidi, N.M.Eisenstein, M.A.Webber, H.Burton, R.J.A.Moakes, O.Addison, M.Attallah, D.E.T.Shepherd, and L.M.Grover (2017) Surface finish has a critical influence on biofilm formation and mammalian cell attachment to additively manufactured prosthetics. ACS Biomaterials Science and Engineering, 3(8), $1616-1626$.

Cross, M.M. (1979) Relation between viscoelasticity and shear-thinning behaviour in liquids. RheologicaActa, 18(5), 609-614.

Cunha, A., A.P.Serro, V.Oliveira, A.Almeida, R.Vilar, and M.C.Durrieu (2013) Wetting behaviour of femtosecond laser textured Ti-6Al-4V surfaces. Applied Surface Science, 265, 688-696.

Dabrowski, L., M.Marciniak, and T.Szewczyk (2006) Analysis of abrasive flow machining with an electrochemical process aid. Proceedings of the Institution of Mechanical Engineers, Part B: Journal of Engineering Manufacture, 220, 397-403.

Das, M., V.K.Jain, and P.S.Ghoshdastidar (2012b) Computational fluid dynamics simulation and experimental investigations into the magnetic-field-assisted nano-finishing process. Proceedings of the Institution of Mechanical Engineers, Part B: Journal of Engineering Manufacture, 226(7), 1143-1158.

Das, M., V.K.Jain, and P.S.Ghoshdastidar (2012a) Nanofinishing of flat workpieces using rotational - magnetorheological abrasive flow finishing (R-MRAFF) process. International Journal of Advanced Manufacturing Technology, 62, 405-420.

Davies, P.J. and A.J.Fletcher (1995) The assessment of the rheological characteristics of various polyborosiloxane/grit mixtures as utilized in the abrasive flow machining process. Proceedings of the Institution of Mechanical Engineers, Part C: Journal of Mechanical Engineering Science, 209(6), 409-418.

Edwards, K.J. and A.D.Rutenberg (2001) Microbial response to surface microtopography: the role of metabolism in localized mineral dissolution. Chemical Geology, 180(1-4), 19-32.

Essabir, H., D.Rodrigue, R.Bouhfid, and A.E.K.Qaiss (2018) Effect of nylon 6 (PA6) addition on the properties of glass fiber reinforced acrylonitrile-butadiene-styrene. Polymer Composites, 39(1), 14-21.

Fischer, G., M.Bigerelle, K.J.Kubiak, T.G.Mathia, Z.Khatir, and K.Anselme (2014) Wetting of anisotropic sinusoidal surfaces-experimental and numerical study of directional spreading. Surface Topography: Metrology and Properties, 2(4), 044003. 
Fu, Y., H.Gao, X.Wang, and D.Guo (2017) Machining the integral impeller and blisk of aero-engines: a review of surface finishing and strengthening technologies. Chinese Journal of Mechanical Engineering (English Edition), 30(3), 528-543.

Gadelmawla, E.S., M.M.Koura, T.M.A.Maksoud, I.M.Elewa, and H.H.Soliman (2002) Roughness parameters. Journal of Materials Processing Technology, 123(1), 133-145.

Garg, H., G.Bedi, and A.Garg (2012) Implantsurface modifications: a review. Journal of Clinical and Diagnostic Research, 6(2), 319-324. doi:https://doi.org/JCDR/2012/ 3642:1937.

Ghanbari, A. and M.M.Attar (2014) Surface free energy characterization and adhesion performance of mild steel treated based on zirconium conversion coating: a comparative study. Surface and Coatings Technology, 246, 26-33.

Gorana, V.K., V.K.Jain, and G.K.Lal (2004) Experimental investigation into cutting forces and active grain density during abrasive flow machining. International Journal of Machine Tools and Manufacture, 44(2-3), 201-211.

Gov, K., O.Eyercioglu, and M.V.Cakir (2013) Hardness effects on abrasive flow machining. Journal of Mechanical Engineering, 59, 626-631.

Graf, W. (2015) Polish grinding of gears for higher transmission efficiency. American Gear Manufacturers Association (AGMA) Fall Technical Meeting, Detroit, MI, 15FTM21.

Gui, N., W.Xu, J.Tian, G.Rosengarten, M.Brandt, and M.Qian (2018) Fabrication and anisotropic wettability of titanium-coated microgrooves. Journal of Applied Physics, 123(9), 095306.

Guo, P., Y.Lu, K.F.Ehmann, and J.Cao (2014) Generation of hierarchical micro-structures for anisotropic wetting by elliptical vibration cutting. CIRP Annals - Manufacturing Technology, 63(1), 553-556.

Harkous, A., G.Colomines, E.Leroy, P.Mousseau, and R.Deterre (2016) The kinetic behavior of liquid silicone rubber: a comparison between thermal and rheological approaches based on gel point determination. Reactive and Functional Polymers, 101, 20-27.

Hashimoto, F., H.Yamaguchi, P.Krajnik, K.Wegener, R.Chaudhari, H.W.Hoffmeister, and F.Kuster (2016) Abrasive fine-finishing technology. CIRP Annals - Manufacturing Technology, 65(2), 597-620.

Hauslich, L.B., M.N.Sela, D.Steinberg, G.Rosen, and D.Kohavi (2013) The adhesion of oral bacteria to modified titanium surfaces: role of plasma proteins and electrostatic forces. Clinical Oral Implants Research, 24, 49-56.

Heisel, U. and J.Avroutine (2001) Process analysis for the evaluation of the surface formation and removal rate in lapping. Annals of the CIRP, 50(1), 229-232.

Hocevar, M., M.Jenko, M.Godec, and D.Drobne (2014) An overview of the influence of stainless-steel surface properties on bacterial adhesion. Materials and Technology, 48(48), 609-617.

Hull, J.B., D.O'Sullivan, A.J.Fletcher, S.A.Trengove, and J.Mackie (1992) Rheology of carrier media used in abrasive flow machining. Key Engineering Materials Vols, 72-74, 617-626.

Jain, R.K. and V.K.Jain (1999) Simulation of surface generated in abrasive flow machining process. Robotics and Computer-Integrated Manufacturing, 15, 403-412.

Jain, R.K. and V.K.Jain (2001) Specific energy and temperature determination in abrasive flow machining process. International Journal of Machine Tools and Manufacture, 41, 1689-1704. 
Jain, R.K. and V.K.Jain (2004) Stochastic simulation of active grain density in abrasive flow machining. Journal of Materials Processing Technology, 152(1), 17-22.

Jain, R.K., V.K.Jain, and P.M.Dixit (1999) Modeling of material removal and surface roughness in abrasive flow machining process. International Journal of Machine Tools and Manufacture, 39(12), 1903-1923.

Jain, V.K. and S.G.Adsul (2000) Experimental investigations into abrasive flow machining (AFM). International Journal of Machine Tools and Manufacture, 40, 1003-1021.

Jain, V.K., C.Ranganatha, and K.Muralidhar (2001) Evaluation of rheological properties of medium for AFM process. Machining Science and Technology, 5(2), 151-170.

Jha, S. and V.K.Jain (2004) Design and development of the magnetorheological abrasive flow finishing (MRAFF) process. International Journal of Machine Tools and Manufacture, 44, 1019-1029.

Jung, D., W.L.Wang, A.Knafl, T.J.Jacobs, S.J.Hu, and D.N.Assanis (2008) Experimental investigation of abrasive flow machining effects on injector nozzle geometries, engine performance, and emissions in a DI diesel engine. International Journal of Automotive Technology, 9(1), 9-15.

Kang, C.-W. and F.-Z.Fang (2018) State of the art of bioimplants manufacturing: part I. Advances in Manufacturing, 6(1), 20-40.

Kanthababu, M., M.S.Shunmugam, and M.Singaperumal (2009) Identification of significant parameters and appropriate levels in honing of cylinder liners. International Journal of Machining and Machinability of Materials, 5(1), 80-96.

Kar, K.K., N.L.Ravikumar, P.B.Tailor, J.Ramkumar, and D.Sathiyamoorthy (2009a) Preferential media for abrasive flow machining. Journal of Manufacturing Science and Engineering, 131(1), 011009.

Kar, K.K., N.L.Ravikumar, P.B.Tailor, J.Ramkumar, and D.Sathiyamoorthy (2009b) Performance evaluation and rheological characterization of newly developed butyl rubber based media for abrasive flow machining process. Journal of Materials Processing Technology, 209(4), 2212-2221.

Katsikogianni, M. and Y.F.Missirlis (2004) Concise review of mechanisms of bacterial adhesion to biomaterials and of techniques used in estimating bacteria-material interactions. European Cells and Materials, 8, 37-57.

Kavithaa, T.S. and N.Balashanmugam (2016) Nanometric surface finishing of typical industrial components by abrasive flow finishing. The International Journal of Advanced Manufacturing Technology, 85, 2189-2196.

Kemaloglu, S., G.Ozkoc, and A.Aytac (2010) Properties of thermally conductive micro and nano size boron nitride reinforced silicon rubber composites. ThermochimicaActa, 499(1-2), 40-47.

Kenda, J., J.Duhovnik, J.Tavcar, and J.Kopac (2014) Abrasive flow machining applied to plastic gear matrix polishing. International Journal of Advanced Manufacturing Technology, 71(1-4), 141-151.

Kim, J.-D. and K.-D.Kim (2004) Deburring of burrs in spring collets by abrasive flow machining. International Journal of Advanced Manufacturing Technology, 24, 469-473.

Koseki, H., A.Yonekura, T.Shida, I.Yoda, H.Horiuchi, Y.Morinaga, K.Yanagihara, H.Sakoda, M.Osaki, and M.Tomita (2014) Early staphylococcal biofilm formation on solid orthopaedic implant materials: in vitro study. PLoS One, 9(10), 1-8.

Kubiak, K.J., M.C.T.Wilson, T.G.Mathia, and P.Carval (2011) Wettability versus roughness of engineering surfaces. Wear, 271, 523-528. 
Kumar, S., V.K.Jain, and A.Sidpara (2015) Nanofinishing of freeform surfaces (knee joint implant) by rotational-magnetorheological abrasive flow finishing (R-MRAFF) process. Precision Engineering, 42, 165-178.

Laheurte, R., P.Darnis, N.Darbois, O.Cahuc, and J.Neauport (2012) Subsurface damage distribution characterization of ground surfaces using abbott-firestone curves. Optics Express, 20(12), 13551.

Law, K.-Y. and H.Zhao (2016) Surface Wetting: Characterization, Contact Angle, and Fundamentals, Springer International Publishing, Switzerland.

Li, J., L.Yang, W.Liu, X.Zhang, and F.Sun (2014) Experimental research into technology of abrasive flow machining nonlinear tube runner. Advances in Mechanical Engineering, 6, 752353.

Li, P., J.Xie, and Z.Deng (2015) Characterization of irregularly micro-structured surfaces related to their wetting properties. Applied Surface Science, 335, 29-38.

Liang, Y., L.Shu, W.Natsu, and F.He (2015) Anisotropic wetting characteristics versus roughness on machined surfaces of hydrophilic and hydrophobic materials. Applied Surface Science, 331, 41-49.

Loberg, J., I.Mattisson, S.Hansson, and E.Ahlberg (2010) Characterisation of titanium dental implants I: critical assessment of surface roughness parameters. The Open Biomaterials Journal, 2, 18-35.

Loveless, T.R., R.E.Williams, and K.P.Rajurkar (1994) A study of the effects of abrasive-flow finishing on various machined surfaces. Journal of Materials Processing Technology, 47(1-2), 133-151.

Lysaght, M.J. and J.A.O'Loughlin (2000) Demographic scope and economic magnitude of contemporary organ replacement therapies. ASAIO Journal, 46(5), 515-521.

Mahajan, A. and S.S.Sidhu (2018) Surface modification of metallic biomaterials for enhanced functionality: a review. Materials Technology, 33(2), 93-105.

Mali, H.S. and A.Manna (2010) Optimum selection of abrasive flow machining conditions during fine finishing of al/15 wt\% SiC-MMC using taguchi method. The International Journal of Advanced Manufacturing Technology, 50(9-12), 1013-1024.

Mattox, D.M. (2010) Handbook of Physical Vapor Deposition (PVD) Processing, 2nd Edition, William Andrew Imprint of Elsevier, Kidlington, London.

May, A., A.Agarwal, J.Lee, M.Lambert, C.K.Akkan, F.P.Nothdurft, and O.C.Aktas (2015) Laser induced anisotropic wetting on Ti-6Al-4V surfaces. Materials Letter, 138, 21-24.

Menezes, P.L., S.V.Kailas, and M.R.Lovell (2013) Fundamentals of Engineering Surfaces. Tribology for Scientists and Engineers, Springer, New York.

Mezger, T.G. (2006) The Rheology Handbook, 2nd Edition, Vincentz Network, Hannover, Germany.

Moriarty, T.F., R.Kuehl, T.Coenye, W.-J.Metsemakers, M.Morgenstern, E.M.Schwarz, M. Riool, S.A.J.Zaat, N.Khana, and S.L.Kates (2016) Orthopaedic device-related infection: current and future interventions for improved prevention and treatment. EFORT Open Reviews, 1(4), 89-99.

Mortimer, C.J., L.Burke, and C.J.Wright (2016) Microbial interactions with nanostructures and their importance for the development of electrospunnanofibrous materials used in regenerative medicine and filtration. Journal of Microbial \& Biochemical Technology, 8, 195-201. 
Navarro, M., A.Michiardi, O.Castano, and J.A.Planell (2008) Biomaterials in orthopaedics. Journal of the Royal Society Interface, 5(27), 1137-1158.

Nuraje, N., W.S.Khan, Y.Lei, M.Ceylan, and R.Asmatulu (2013) Superhydrophobicelectrospunnanofibers. Journal of Materials Chemistry A, 1(6), 1929-1946.

Perry, W.B. and J.Stackhouse (1989) Gas turbine applications of abrasive flow machining. Presented at the Gas Turbine and Aeroengine Congress and Exposition, Toronto, Canada, June 4-8.

Petare, A.C. and N.K.Jain (2018) A critical review of past research and advances in abrasive flow finishing process. The International Journal of Advanced Manufacturing Technology, 97(1-4), 741-782.

Petri, K.I., R.E.Billo, and B.Biclanda (1998) A neural network process model for abrasive flow machining operations. Journal of Manufacturing Systems, 17(1), 52-64.

Pignon, F., A.Magnin, and J.Piau (1996) Thixotropic colloidal suspensions and flow curves with minimum: identification of flow regimes and rheometric consequences. Journal of Rheology, 40(4), 573-587.

Quirynen, M. and C.M.L.Bollen (2005) The influence of surface roughness and surface-free energy on supra- and subgingival plaque formation in man. Journal of Clinical Periodontology, 22(1), 1-14.

Raju, H.P., K.Narayanasamy, Y.G.Srinivasa, and R.Krishnamurthy (2003) Material response in extrusion honing. Journal of Materials Science Letters, 22(5), 367-370.

Rasouli, R., A.Barhoum, and H.Uludag (2018) A review of nanostructured surfaces and materials for dental implants: surface coating, patterning and functionalization for improved performance. Biomaterials Science, 6(6), 1312-1338. doi:https://doi.org/ $10.1039 / \mathrm{c} 8 \mathrm{bm} 00021 \mathrm{~b}$.

Rhoades, L. (1991) Abrasive flow machining: a case study. Journal of Materials Processing Technology, 28, 107-116.

Ribeiro, M., F.J.Monteiro, and M.P.Ferraz (2012) Infection of orthopedic implants with emphasis on bacterial adhesion process and techniques used in studying bacterial-material interactions. Biomatter, 2(4), 176-194.

Rohm, S., C.Knoflach, W.Nachbauer, M.Hasler, L.Kaserer, J.Van Putten, S.H.Unterberger, and R.Lackner (2016) Effect of different bearing ratios on the friction between ultrahigh molecular weight polyethylene ski bases and snow. ACS Applied Materials and Interfaces, 8(19), 12552-12557.

Rulison, C. (1999) So You Want to Measure Surface Energy? KRUSS Technical Notes 306, Borsteler Chausses 85, Hamburg, Germany, 1-8.

Sankar, M.R., V.K.Jain, and J.Ramkumar (2009c) Experimental investigations into rotating workpiece abrasive flow finishing. Wear, 267, 43-51.

Sankar, M.R., V.K.Jain, J.Ramkumar, and Y.M.Joshi (2011) Rheological characterization of styrene-butadiene based medium and its finishing performance using rotational abrasive flow finishing process. International Journal of Machine Tools and Manufacture, 51(12), 947-957.

Sankar, M.R., S.Mondal, and J.Ramkumar (2009b) Experimental investigations and modeling of drill bit-guided abrasive flow finishing (DBG-AFF) process. International Journal of Advanced Manufacturing Technology, 42(7-8), 678-688.

Sankar, M.R., J.Ramkumar, and V.K.Jain (2009a) Experimental investigation and mechanism of material removal in nano finishing of MMCS using abrasive flow finishing (AFF) process. Wear, 266(7-8), 688-698. 
Sharma, A.K., G.Venkatesh, S.Rajesha, and P.Kumar (2015) Experimental investigations into ultrasonic-assisted abrasive flow machining (UAAFM) process. International Journal of Advanced Manufacturing Technology, 80, 477-493.

Shit, S.C. and P.Shah (2013) A review on silicone rubber. National Academy Science Letters, 36(4), 355-365.

Sidpara, A.M. and V.K.Jain (2012) Nanofinishing of freeform surfaces of prosthetic knee joint implant. ProcIMechE Part B: J Engineering Manufacture, 226(11), 1833-1846.

Singh, S. and H.S.Shan (2002) Development of magneto abrasive flow machining process. International Journal of Machine Tools and Manufacture, 42(8), 953-959.

Singh, S., H.S.Shan, and P.Kumar (2008) Experimental studies on mechanism of material removal in abrasive flow machining process. Materials and Manufacturing Processes, 23, 714-718.

Smith, G.T. (2002) Industrial Metrology: Surface and Roundness, 1st Edition, SpringerVerlag, London.

Song, F., H.Koo, and D.Ren (2015) Effects of material properties on bacterial adhesion and biofilm formation. Journal of Dental Research, 94(8), 1027-1034.

Subramani, K., R.T.Mathew, and P.Pachauri (2018) Titanium Surface Modification Techniques for Dental Implants-From Microscale to Nanoscale, Second Edition, Elsevier Inc. doi:https://doi.org/10.1016/B978-0-12-812291-4.00006-6.

Sushil, M., K.Vinod, and K.Harmesh (2015) Experimental investigation and optimization of process parameters of $\mathrm{Al} / \mathrm{SiCMMCs}$ finished by abrasive flow machining. Materials and Manufacturing Processes, 30(7), 902-911.

Sykaras, N., A.M.Iacopino, V.A.Marker, R.G.Triplett, and R.D.Woody (2000) Implant materials, designs, and surface topographies: their effect on osseointegration. A Literature Review Int J Oral Maxillofac Implants, 2000(15), 675-690.

Trengove, S.A. (1993) Extrusion Honing Using Mixtures of Polyborosiloxane and Grit, Ph.D. Thesis, Sheffield Hallam University, Sheffield, England.

Tseng, H.-C., J.-S.Wu, and R.-Y.Chang (2010) Linear viscoelasticity and thermorheological simplicity of $\mathrm{n}$-hexadecane fluids under oscillatory shear via non-equilibrium molecular dynamics simulations. Physical Chemistry Chemical Physics, 12(16), 4051.

Turger, A., J.Kohler, B.Denkena, T.A.Correa, C.Becher, and C.Hurschler (2013) Manufacturing conditioned roughness and wear of biomedical oxide ceramics for allceramic knee implants - Colorado school of mines. BioMedical Engineering OnLine, 12(84), 1-17.

Tzeng, H.J., B.H.Yan, R.T.Hsu, and H.M.Chow (2007a) Finishing effect of abrasive flow machining on micro slit fabricated by wire-EDM. International Journal of Advanced Manufacturing Technology, 34(7-8), 649-656.

Tzeng, H.J., B.H.Yan, R.T.Hsu, and Y.C.Lin (2007b) Self-modulating abrasive medium and its application to abrasive flow machining for finishing micro channel surfaces. International Journal of Advanced Manufacturing Technology, 32(11-12), 1163-1169.

Uhlmann, E., M.Doits, and C.Schmiedel (2013) Development of a material model for visco-elastic abrasive medium in abrasive flow machining. Procedia CIRP, 8, 351-356.

Uhlmann, E., V.Mihotovic, and A.Coenen (2009) Modelling the abrasive flow machining process on advanced ceramic materials. Journal of Materials Processing Technology, 209, 6062-6066. 
van-Oss, C.J., M.K.Chaudhury, and R.J.Good (1988) Interfacial lifshitz-van der waals and polar interactions in macroscopic systems. Chemical Reviews, 88(6), 927-941.

Walia, R.S., H.S.Shan, and P.Kumar (2006a) Abrasive flow machining with additional centrifugal force applied to the media. Machining Science and Technology, 10(3), 341-354.

Walia, R.S., H.S.Shan, and P.Kumar (2006b) Parametric optimization of centrifugal force-assisted abrasive flow machining (CFAAFM) by the taguchi method. Materials and Manufacturing Processes, 21(4), 375-382.

Wang, A.C., K.C.Cheng, K.Y.Chen, and Y.C.Lin (2014) Enhancing the surface precision for the helical passageways in abrasive flow machining. Materials and Manufacturing Processes, 29(2), 153-159.

Wang, A.C., C.H.Liu, K.Z.Liang, and S.H.Pai (2007) Study of the rheological properties and the finishing behavior of abrasive gels in abrasive flow machining. Journal of Mechanical Science and Technology, 21(10), 1593-1598.

Wang, A.C. and S.H.Weng (2007) Developing the polymer abrasive gels in AFM processs. Journal of Materials Processing Technology, 192-193, 486-490.

Wassmann, T., S.Kreis, M.Behr, and R.Buergers (2017) The influence of surface texture and wettability on initial bacterial adhesion on titanium and zirconium oxide dental implants. International Journal of Implant Dentistry, 3(32), 1-11.

Wenzel, R. (1936) Resistance of solid surfaces. Journal of Industrial and Engineering Chemistry, 28(8), 988-994.

Whitehouse, D.J. (2011) Handbook of Surface and Nanometrology, 2nd Edition, CRC Press, Taylor \& Francis Group, Boca Raton, FL, London and New York.

Williams, R.E. (1993) Investigation of the Abrasive Flow Machining Process and Development of a Monitoring Strategy Using Acoustic Emission, Ph.D Thesis, University of Nebraska, Lincoln, NE.

Williams, R.E. (1998) Acoustic emission characteristics of abrasive flow machining. Journal of Manufacturing Science and Engineering, 120(2), 264-271.

Williams, R.E. and K.P.Rajurkar (1992) Stochastic modeling and analysis of abrasive flow machining. Journal of Manufacturing Science and Engineering, 114(1), 74-81.

Winter, H.H. (1987) Can the gel point of a cross-linking polymer be detected by the $\mathrm{G}^{\prime}-\mathrm{G}^{\prime \prime}$ crossover? Polymer Engineering and Science, 27(22), 1698-1702.

$\mathrm{Wu}, \mathrm{S}$. (1982) Polymer Interface and Adhesion, $1^{\text {st }}$ Edition, CRC Press, New York.

$\mathrm{Xu}$, Y.C., K.H.Zhang, S.Lu, and Z.Q.Liu (2013) Experimental investigations into abrasive flow machining of helical gear. Key Engineering Materials, 546, 65-69.

Yan, Y., E.Chibowski, and A.Szczes (2017) Surface properties of Ti-6Al-4V alloy part I: surface roughness and apparent surface free energy. Materials Science and Engineering: $C, \mathbf{7 0}, 207-215$.

Yin, L., K.Ramesh, S.Wan, X.D.Liu, H.Huang, and Y.C.Liu (2004) Abrasive flow polishing of micro bores. Materials and Manufacturing Processes, 19(2), 187-207.

Yoda, I., H.Koseki, M.Tomita, T.Shida, H.Horiuchi, H.Sakoda, and M.Osaki (2014) Effect of surface roughness of biomaterials on staphylococcus epidermidis adhesion. BMC Microbiology, 14(1), 1-7.

Zhou, W., S.Qi, H.Zhao, and N.Liu (2007) Thermally conductive silicone rubber reinforced with boron nitride particle. Polymer Composites, 28(1), 23-28. 